\title{
Impacts of drying and reflooding on water quality of a tropical semi-arid reservoir during an extended drought event
}

\author{
Impactos do esgotamento hídrico e reinundação na qualidade da água de um \\ reservatório da regiáo tropical semiárida durante evento de seca prolongada
}

\section{Jéssica Nayara de Carvalho Leite ${ }^{1}$ (D) and Vanessa Becker ${ }^{1,2}$ (D)}

\begin{abstract}
${ }^{1}$ Programa de Pós-graduação em Engenharia Sanitária, Universidade Federal do Rio Grande do Norte - UFRN, Av. Senador Salgado Filho, 3000, Campus Universitário, CEP 59078-970, Natal, RN, Brasil

${ }^{2}$ Departamento de Engenharia Civil, Universidade Federal do Rio Grande do Norte - UFRN, Av. Senador Salgado Filho, 3000, Campus Universitário, CEP 59078-970, Natal, RN, Brasil *e-mail: becker.vs@gmail.com
\end{abstract}

Cite as: Leite, J.N.C. and Becker, V. Impacts of drying and reflooding on water quality of a tropical semi-arid reservoir during an extended drought event. Acta Limnologica Brasiliensia, 2019, vol. 31, e15.

\begin{abstract}
Aim: The aim of this study was to analyze the water quality of a tropical, semi-arid reservoir after a reflooding. In terms of impact on water quality after a drought event, it is expected that there will be improvements with the reflooding. Less algal biomass, increased water transparency, decreased turbidity and low nutrient concentration. Methods: This study was performed in a tropical, semi-arid man-made lake (Dourado Reservoir), during an extended drought period. This study consisted of a comparison of three distinct periods determined by water accumulation. The limnological variables, including water transparency, turbidity, electrical conductivity, $\mathrm{pH}$, total phosphorus, soluble reactive phosphorus, and chlorophyll- $a$ were analyzed. A principal component analysis (PCA) was also performed to verify the patterns of the variables in relation to the sample units in the studied periods. Results: After water renewal, there was an expressive reduction in chlorophyll- $a$. Electrical conductivity, $\mathrm{pH}$, and turbidity variables also reduced after the reflooding, indicating an improvement in water quality. There was no reduction in total phosphorus and soluble reactive phosphorus after the reflooding compared to the previous periods. Conclusions: The significant reduction in algal biomass after reflooding in Dourado indicates water quality improvement in terms of eutrophication due to the change of the trophic state from eutrophic to mesotrophic.
\end{abstract}

Keywords: man-made lakes; shallow; drylands; eutrophication.

Resumo: Objetivo: O objetivo deste estudo foi analisar a qualidade da água de um reservatório do semiárido tropical após esgotamento hídrico durante um evento de seca prolongada. Em termos de impactos na qualidade da água, após um evento de esgotamento hídrico é esperado que haja melhorias com a renovaçấo das águas. Menor biomassa algal, maior transparência da água, menor turbidez e baixa concentração de nutrientes. Métodos: O reservatório estudado foi Dourado, localizado no semiárido brasileiro. $\mathrm{O}$ trabalho foi realizado com três períodos distintos, determinados de acordo com o volume hídrico. Os períodos foram marcados por chuvas abaixo da média histórica anual, estando assim inseridos em um período de estiagem prolongada. Foram analisadas as variáveis transparência da água, turbidez, condutividade elétrica, $\mathrm{pH}$, fósforo total, fósforo reativo dissolvido e clorofila- $a$. Foi também realizada uma análise de componentes principais (ACP) para verificar os padróes das variáveis em reação às unidades amostrais. Resultados: Após a renovação das águas, houve uma expressiva redução na clorofila- $a$. As variáveis condutividade elétrica, $\mathrm{pH}$ e turbidez também sofreram 
redução após a renovação das águas. Não houve redução após o aporte de água para fósforo total e fósforo reativo dissolvido, em comparação aos períodos anteriores. Conclusóes: A significativa redução da biomassa algal após a reinundaçáo de Dourado indica melhora na qualidade da água em termos de eutrofização, diante da mudança do estado de trofia de eutrófico para mesotrófico.

Palavras-chave: lagos artificiais; rasos; regióes secas; eutrofização.

\section{Introduction}

Especially in dry regions, man-made lakes promote greater water security to meet the demands of human supply and agricultural irrigation, especially during periods of extended drought (Rebouças, 1997). These systems are very sensitive to changes in regional environmental conditions. The climatic variables influencing the process of water level fluctuation and the use and occupation of drainage basins become factors that directly influence the water quality of a reservoir (Straškraba \& Tundisi, 1999; Beklioglu et al., 2007; Jeppesen et al., 2015).

Some reservoirs reach such low water volumes that they are no longer sufficient for supply, thus discontinuing the water intake, or even drying completely at a certain frequency, going through periods of prolonged drought, due to the high evaporation rate (Abbaspour et al., 2012). In a region with periods of reduced rainfall, the reduction of the water volume of the aquatic systems and the increase of the residence time intensify the eutrophication process, resulting in increased turbidity, conductivity, salinity, nutrient concentration and phytoplankton biomass, including cyanobacteria blooms occurrence (Bouvy et al., 2003; Özen et al., 2010; Braga et al., 2015). Moreover, due to the lower water depth, the phosphorus stored in the sediment can be resuspended by several processes, such as the action of the winds and benthivorous fish, intensifying internal fertilization and, consequently, eutrophication (Beklioglu et al., 2007; Araújo et al., 2016; Costa et al., 2016).

Development of climate models by the Intergovernmental Panel on Climate Change (IPCC), indicate that arid and semi-arid areas can be more susceptible to climate change (IPCC, 2014). Projections of future climatic aspects have shown scenarios of extreme events, such as intense rainfall during short periods and severe droughts (IPCC, 2014). It is expected that drought events occur more frequently in the future and with major intensity in environments from semi-arid to arid climates due to climatic warming (Jeppesen et al., 2009; Roland et al., 2012). Semi-arid watersheds in Brazil tend to be more sensitive to reduced rainfall and water flow compared to humid tropical systems (Marengo \& Valverde, 2007; Roland et al., 2012), which may lead to changes in water levels and hydraulic retention times.

In the northeastern semi-arid region, drought is recurrent in some reservoirs, which remain dry for months or even years, and represents a serious problem for the water supply. In the last years several studies in this region have reported the intensification and worsening of eutrophication due to the extreme drought events, mainly due to the low water volume and the concentration of nutrients from an autochthonous source (Braga et al., 2015; Brasil et al., 2016; Medeiros et al., 2015; Costa et al., 2016; Figueiredo \& Becker, 2018; Costa et al., 2019).

After a drought event, it is expected that there will be improvement after precipitation. In addition, depletion of reservoirs may be a tool in regions that do not suffer from water scarcity to improve water quality (Teferi et al., 2014). Aspects, such as less phytoplankton blooms, greater water transparency, less turbidity, more abundant aquatic vegetation, and low concentration of nutrients, were observed in previous studies on water quality after reflooding in dry reservoirs (Prophet, 1970; Scholz et al., 2002; Van Geest et al., 2005; Teferi et al., 2014).

The impacts of extreme hydrological events on the water quality of semi-arid reservoirs are not yet fully understood, as well as the effects of complete drying for reservoir ecology in tropic and subtropical regions (Jeppesen et al., 2015). In light of this, understanding how the water level fluctuations and water renewal events can affect the water quality, especially in drylands, can be a crucial tool for water management and restoration of lakes. Thus, the aim of this study was to analyze the water quality of a tropical semi-arid reservoir, before and after an extended drought event. The hypothesis was that the water sample taken after reflooding would show better quality than the previous sample.

\section{Materials and methods}

\subsection{Study site}

This study was performed in Dourado reservoir $\left(06^{\circ} 14^{\prime} 48^{\prime \prime} S\right.$; 36 30'30"W), located in Currais Novos city, northeast of Brazil (Figure 1). 
This tropical man-made lake was built in 1982 from the impoundment of São Bento River for multiple uses as water supply, irrigated agriculture, livestock, fishing and recreation. Dourado's lake water capacity is around $10,300,000 \mathrm{~m}^{3}$, with a surface area of $3.16 \mathrm{~km}^{2}$ and maximum depth of $10 \mathrm{~m}$ (SEMARH, 2001). The hydrographic sub-basin of the reservoir has an area of $478.93 \mathrm{~km}^{2}$, and a perimeter of $107.67 \mathrm{~km}$. The average insolation of the region is 3000 light hours per year, associated with average temperatures always higher than $22^{\circ} \mathrm{C}$ and average annual relative humidity of $64 \%$.

The regional climate is tropical, semi-arid BS' $\mathrm{h}$ (low latitude and altitude; Alvares et al., 2014), characterized by irregular rainfall (average rainfall of $550 \mathrm{~mm}$.year ${ }^{-1}$, characterized by a rainy season between the months from February to May), high evapotranspiration rates, and negative water balance during most of the year (Braga et al., 2015; ANA,
2016). As such, Dourado is a reservoir that dries with regular recurrence over the years. In December 2014 , there were only $1,113.75 \mathrm{~m}^{3}$ of water in Dourado, corresponding to $0.01 \%$ of the total capacity.

This work was carried out in three different periods determined by the reservoir's water volume (Figure 2): Period I - January to December 2012; Period II - January to December 2014; Period III April 2016 to March 2017. In Period I, the behavior of the water volume was similar to that of Period III, the latter representing the twelve months after the reservoir began to receive precipitation again (Figure 2). Period II represents the twelve months that preceded Dourado's dry state.

\subsection{Sampling and analysis}

The samples were taken near the dam at the deepest point of the reservoir (Figure 1). They were integrated with the entire water column using a
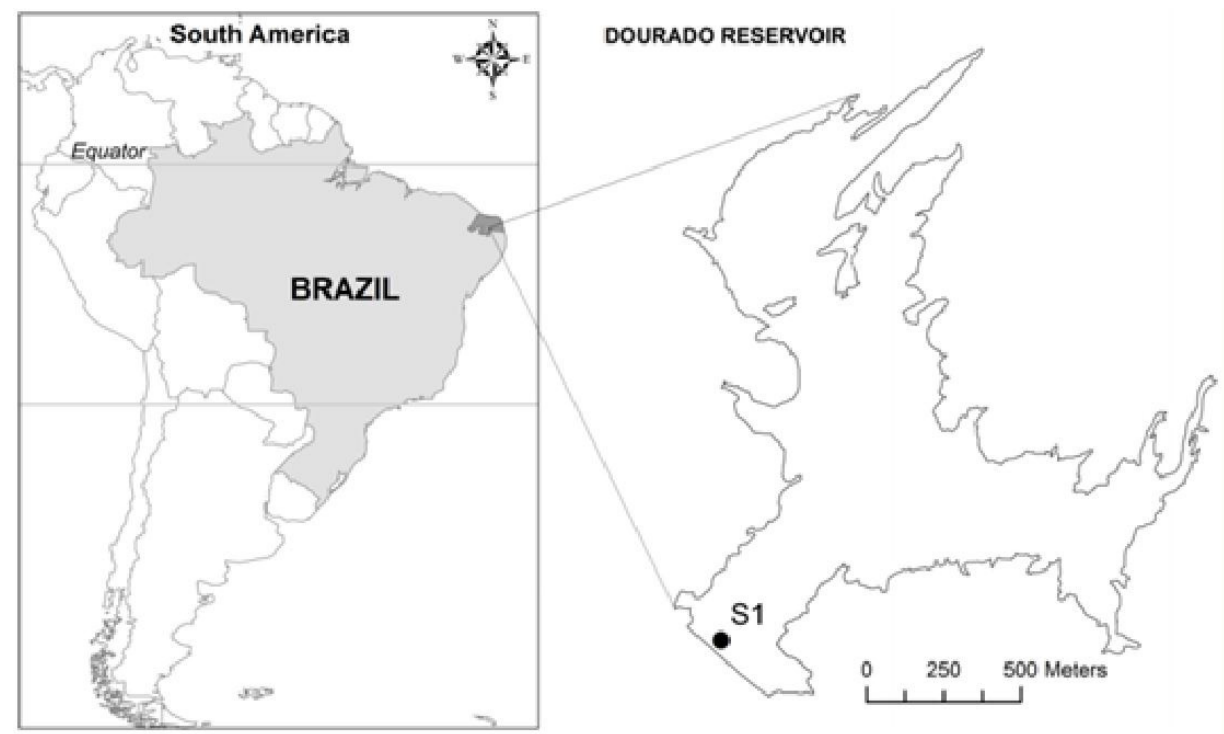

Figure 1. Location of Dourado reservoir. S1: Sampling point.

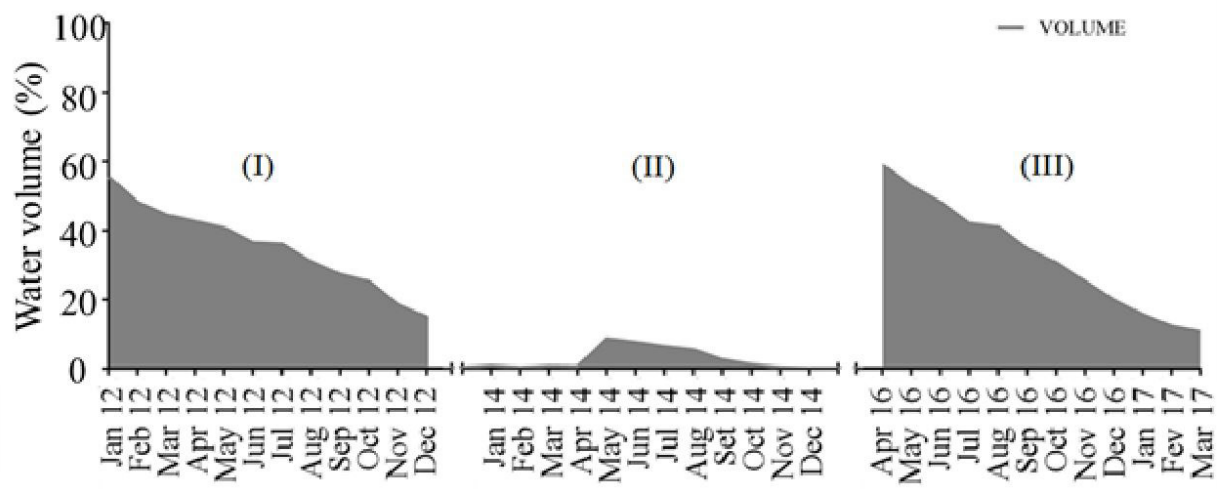

Figure 2. Periods studied and respective water volume accumulation (\%) in Dourado reservoir. 
Van Dorn bottle and were then conditioned in previously cleaned plastic bottles with $10 \% \mathrm{HCl}$ and deionized water, which were stored in ice in a thermal box until arrival at the laboratory.

Water transparency (SECCHI) was measured using the Secchi disk. In the laboratory, the turbidity (TURB) was measured with a turbidimeter (PoliControl AP2000), and the electrical conductivity (EC) was measured by a conductivity meter (Tec-4MP). The turbidity was expressed in NTU (Nephelometric Turbidity Unit) and the conductivity in $\mu \mathrm{S} \mathrm{m}^{-1}$.

The total phosphorus (TP) analysis was performed by spectrophotometry using the ascorbic acid method after oxidation with potassium persulfate (Valderrama, 1981; Murphy \& Riley, 1962). The concentration of soluble reactive phosphorus (SRP) was determined by spectrophotometry with the samples previously filtered in glass fiber $(\varnothing=47 \mathrm{~mm}$ and $1.2 \mu \mathrm{m}$ porosity) (Murphy \& Riley, 1962). Chlorophyll-a (CHLA) was extracted from fiber filters with 95\% ethanol (Jespersen \& Christoffersen, 1987). The nutrient concentrations and chlorophyll-a were

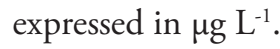

The classification of trophic states, defined by Thornton \& Rast (1993), using TP and CHLA values was used to categorize the trophic state of the reservoir as mesotrophic $\left(\mathrm{PT}<50 \mu \mathrm{g} \mathrm{L}^{-1}\right.$ and CHLA $<15 \mu \mathrm{g} \mathrm{L}^{-1}$ ) and eutrophic (TP $>50 \mu \mathrm{g} \mathrm{L}^{-1}$ and CHLA $>15 \mu \mathrm{g} \mathrm{L}^{-1}$ ).

Precipitation data from the region were provided by the Agricultural Research Company of Rio Grande do Norte (EMPARN). The accumulated water volume data taken from the Dourado reservoir, during the studied period, were provided by the State Department of Environment and Water
Resources of Rio Grande do Norte (SEMARH) and then converted to percentage values.

\subsection{Statistical analysis}

Using PC-ORD ${ }^{\circledR}$ software version 6.08, a principal component analysis (PCA) with the studied variables was also performed to verify patterns of the variables in relation to the sample units in the studied periods (McCune \& Mefford, 2011).

\section{Results}

The three study periods exhibited rainfall below the annual historical average and, thus, were a part of a prolonged drought period (Figure 3).

In the temporal dynamic of the limnological variables (Secchi transparency, turbidity, total phosphorus, electrical conductivity, soluble reactive phophorus and Chlorophyll-a), a tendency was observed to improve water quality after reflooding (Figure 4). The lower SECCHI was recorded in the period before to the drying (Period II), while after refilling the values increased. TURB in Period III remained low (mean value: 19.8 NTU), except for the first month when a large increase occurred (273 UNT) due to the tributary's entrance. EC and $\mathrm{pH}$ presented lower values in Period III (after refilling). TP was higher in Period II (before to the drying), although values were high throughout the study. The concentration of SRP in Periods I and II were lower than the values in Period III (Figure 4). Dourado reservoir also showed a decrease in chlorophyll- $a$ (CHLA) concentrations when compared to periods I (average: $103.7 \mu \mathrm{g} \mathrm{L}^{-1}$ ) e II (average: $270.4 \mu \mathrm{g} \mathrm{L}^{-1}$ ) from Period III (average $12.6 \mu \mathrm{g} \mathrm{L}^{-1}$ ) (Figure 4).

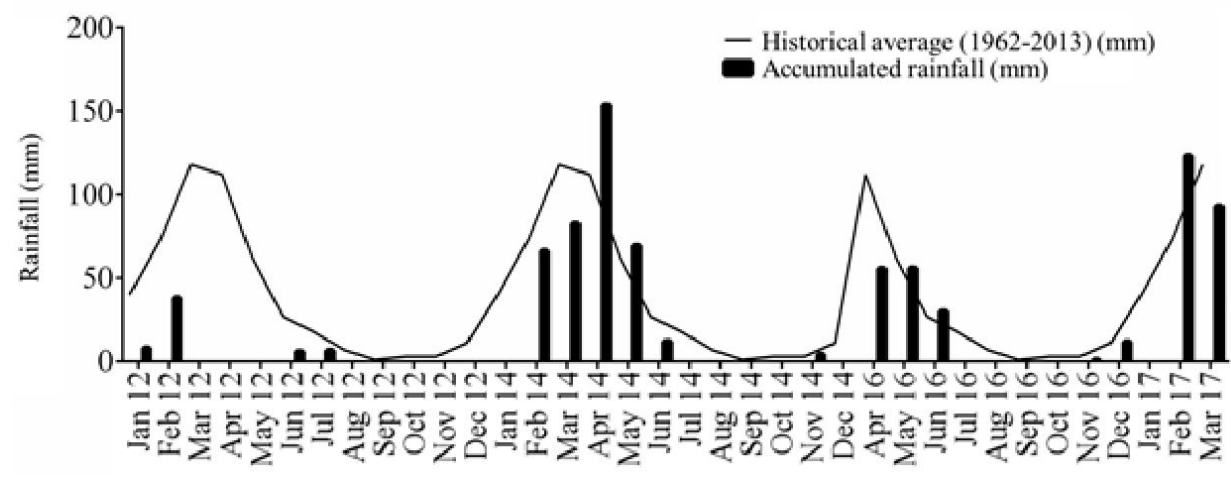

Figure 3. Historical average precipitation and precipitation in Periods I, II and III for Currais Novos (EMPARN and INMET). 

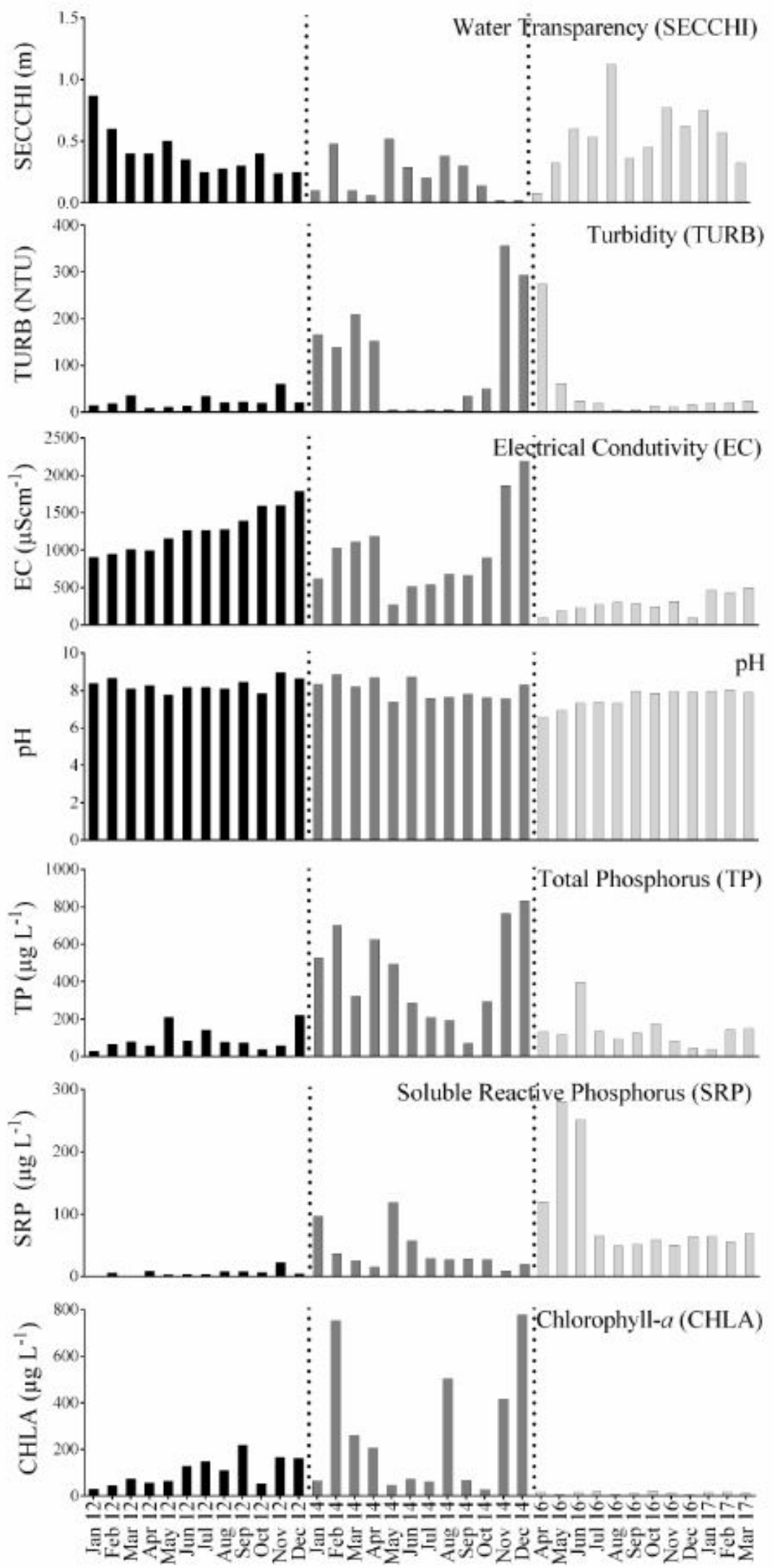

Figure 4. Temporal dynamic of the limnological variables: Secchi Transparency (SECCHI), Turbidity (TURB), Electrical Conductivity (EC), pH, Total Phosphorus (TP), Soluble Reactive Phophorus (SRP) and Chlorophyll- $a$ (CHLA). 


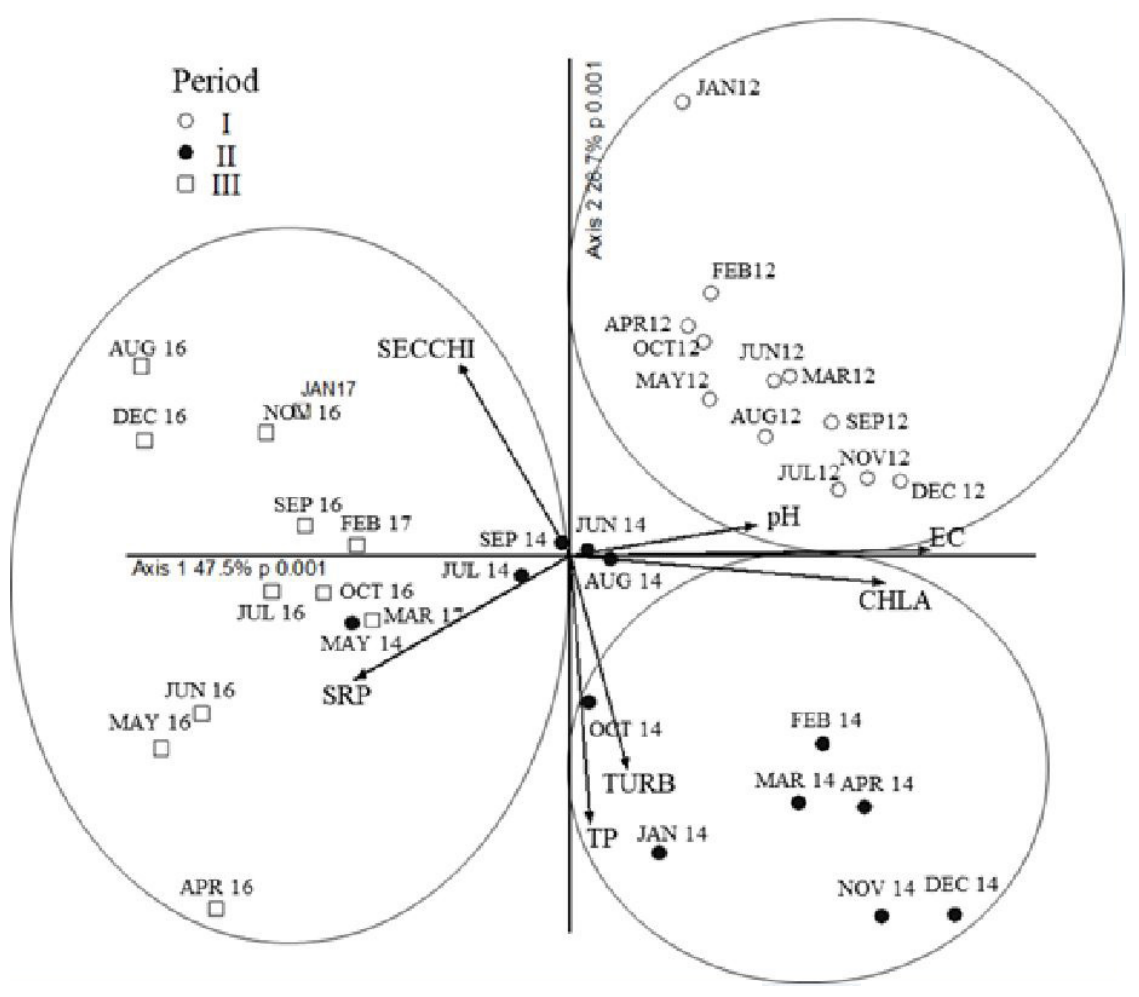

Figure 5. Principal components analysis of the limnological variables studied in Dourado during Periods I, II and III. Variables: TP = Total Phosphorus; SRP = Soluble Reactive Phosphorus; CHLA = chlorophyll $-a$; TURB = Turbidity; SECCHI = Water transparency; EC = Electrical Conductivity.

Principal component analysis (PCA) showed that the sample units segregated between the periods before and after the reservoir dried (Figure 5). The PCA explained $76.2 \%$ of the variance in the first two axis (Axis 1: 47.5\%, Axis 2: 28.7\%). Electrical conductivity (0.94), chlorophyll- $a(0.83)$ and $\mathrm{pH}(0.68)$ were positively related to axis 1 $(P=0.001)$, while soluble reactive phosphorus $(-0.73)$ was negatively related to this axis. Water transparency (0.69) was positively related to axis $2(P=0.001)$ while turbidity $(-0.73)$ and total phosphorus $(-0.81)$ were negatively related to this axis. Axis 1 showed a temporal trend according to water renewal after a drought. On the positive side were the sample units for Periods I and II, before the drought, while the sample units for Period III, reflooding after drying, were on the negative side). We observed that Axis 1 had a higher value of SRP and lower values of CHLA, EC, and $\mathrm{pH}$ for the reflooding period (III). Axis 2 had a higher SECCHI value and lower PT and TURB values for Period I.

\section{Discussion}

Extreme events promote a huge vulnerability for continental aquatic bodies due to the process of water level fluctuation, which is directly linked to quality in physical, chemical, and biological aspects, especially in the semi-arid region (Brasil et al., 2016; Figueiredo \& Becker, 2018; Costa et al., 2019). The prolonged drought that occurred in the study area contributed to significant changes in the water quality of Dourado over the study periods, besides favoring the event of water depletion of the reservoir. The results point out differences in the water quality of Dourado before and after water renewal for some of the studied variables, indicating an improvement in water quality in terms of eutrophication. It is worth pointing out that in the Brazilian semi-arid region, the drought of the years 2012, 2013 and 2014 was the worst drought of the last 60 years, according by National Water Agency (ANA) (Figueiredo \& Becker, 2018).

Despite reflooding, water transparency didn't seem to improve, which is probably due to the great transport of organic and inorganic matter from the drainage basin during water renewal. The water transparency was lower before the drought, possibly due to the low water volume and resulting higher algal biomass concentration (Coops et al., 2003) during this period. The turbidity, due to the resuspension of sediments and entrance of material carried to the reservoir, presented a high 
values in the first month of analysis of this period post-reflooding, that influenced its twelve months average to remain similar to the previous periods. However, the low turbidity values in the later months indicated an improvement in water quality relative to this variable, which was as expected when the reservoir refilled. The electrical conductivity also improved in the reflooding period. The increased salinity, promoted by drought events associated with a warmer climate, typically affects the trophic structure of shallow lakes and their ecological quality (Jeppesen et al., 2015). Thus, reservoirs like Dourado are more susceptible to these impacts.

The lower algal biomass post-reflooding, and the resulting lower photosynthetic consumption of carbon dioxide, could explain the lower $\mathrm{pH}$ during this period (Scholz et al., 1999) than before. The total phosphorus presented higher concentrations before the drying event, which can be explained by the lower water volume and higher chlorophyll- $a$ concentration; similarities between concentrations in Periods I and III would not be expected due to reflooding and the lower algal biomass in the last period. However, the origin of the largest amount of total phosphorus may be in the organic matter already present in the reservoir when refilling (Scholz et al., 2002). As for the soluble reactive phosphorus, which was higher after the renewal, it is possible that there was not enough time for nutrient consumption by phytoplankton and establishment of algal biomass. In addition, the availability of soluble reactive phosphorus in the water column is influenced by biological processes, such as the degradation of organic forms of phosphorus by bacteria, lysis and cellular excretion of phytoplankton and physicochemical transformations, sediment adsorption capacity and interactions of organic particles with cations like $\mathrm{Fe}$ and $\mathrm{Ca}$, would soon require a more in-depth study of the processes present in the water to better understand the results for the nutrient. Furthermore, studies show that the drying-flooding process of lake sediments may increase the potential release of phosphorus in the water body depending on environmental conditions (Dieter et al., 2015). This may also contribute to the higher concentration of reactive phosphorus dissolved in Dourado in Period III in relation to the other periods, indicating that sediment management is also important to avoid future eutrophication processes.

The factor that stands out in water quality improvement after reflooding in Dourado is the reduction of phytoplankton biomass: the trophic state changed from eutrophic to mesotrophic. This aspect is of great importance because of the lower risk of potentially toxic cyanobacteria blooms whose presence in Brazilian semi-arid reservoirs has already been reported (Panosso et al., 2007; Costa et al., 2009; Moura et al., 2018). Despite this trophic state change, the internal loading of phosphorus from sediment (autochthonous source) can returned the high nutrients concentration. It can only be a temporary change if there are no some mitigation and management actions in the reservoir and its basin.

Changes in precipitation and evaporation caused by climate change will aggravate the symptoms of eutrophication (Moss et al., 2011), and there are predictions that drier climate regions will be more sensitive to these changes. Thus, understanding how water level fluctuations, as well as a reflooding event can affect the quality of a water body is very important, especially in drylands, also used as a useful management tool in periods of hydric crisis (prolonged drought events).

\section{Acknowledgements}

We would like to thank FINEP (Financier of Studies and Projects) and CNPq (Brazilian National Research Council), process n ${ }^{\circ} 52009$, and Universal Project CNPq (Brazilian National Research Council), process $\mathrm{n}^{\circ} 407783 / 2016-4$, for financial support. We also thank Professor Arthur Mattos (in memoriam) for his support and coordination, as well as Aline Figueiredo, Carlos A.N. Rocha Júnior, Daniel Medeiros, Débora Xavier, Gabriela Trigueiro, Gustavo Braga, Herika Cavalcante, Ingridh Diniz, Jurandir Mendonça Júnior, Laíssa Torres, Neuciano de Oliveira, Raul Leite da Costa, and Silvana S. Gomes for technical support, field sampling, and laboratory analyses.

\section{References}

ABBASPOUR, M., JAVID, A.H., MIRBAGHERI, S.A., AHMADI GIVI, F. and MOGHIMI, P. Investigation of lake drying attributed to climate change. International Journal of Environmental Science and Technology, 2012, 9(2), 257-266. http://dx.doi. org/10.1007/s13762-012-0031-0.

AGÊNCIA NACIONAL DE ÁGUAS - ANA. Plano de Recursos Hidricos Piancó-Piranhas-Açu. Resumo Executivo. Brasília: ANA, 2016.

ALVARES, C.A., STAPE, J.L., SENTELHAS, P.C., MORAES GONÇALVES, J.L. and SPAROVEK, G. Köppen's climate classification map for Brazil. Meteorologische Zeitschrift, 2014, 22(6), 711-728. http://dx.doi.org/10.1127/0941-2948/2013/0507. 
ARAÚJO, F., BECKER, V. and ATTAYDE, J.L. Shallow lake restoration and water quality management by the combined effects of polyaluminium chloride addition and benthivorous fish removal: a field mesocosm experiment. Hydrobiologia, 2016, 778(1), 243-252. http://dx.doi.org/10.1007/s10750-015-2606-5.

BEKLIOGLU, M., ROMO, S., KAGALOU, I., QUINTANA, X. and BÉCARES, E. State of the art in the functioning of shallow Mediterranean lakes: workshop conclusions. Hydrobiologia, 2007, 584(1), 317-326. http://dx.doi.org/10.1007/s10750007-0577-x.

BOUVY, M., NASCIMENTO, S.M., MOLICA, R.J., FERREIRA, A., HUSZAR, V. and AZEVEDO, S.M. Limnological features in Tapacurá reservoir (northeast Brazil) during a severe drought. Hydrobiologia, 2003, 493(1-3), 115-130. http:// dx.doi.org/10.1023/A:1025405817350.

BRAGA, G.G., BECKER, V., OLIVEIRA, J.N.P., MENDONÇA JUNIOR, J.R., BEZERRA, A.F.M., TORRES, L.M., GALVÃO, Â.M.F. and MATTOS, A. Influence of extended drought on water quality in tropical reservoirs in a semiarid region. Acta Limnologica Brasiliensia, 2015, 27(1), 15-23. http:// dx.doi.org/10.1590/S2179-975X2214.

BRASIL, J., ATTAYDE, J.L., VASCONCELOS, F.R., DANTAS, D.D.F. and HUSZAR, V.L.M. Droughtinduced water-level reduction favors cyanobacteria blooms in tropical shallow lakes. Hydrobiologia, 2016, 770(1), 145-164. http://dx.doi.org/10.1007/ s10750-015-2578-5.

COOPS, H., BEKLIOGLU, M. and CRISMAN, T.L. The role of water-level fluctuations in shallow lake ecosystems-workshop conclusions. Hydrobiologia, 2003, 506(1-3), 23-27. http://dx.doi.org/10.1023/ B:HYDR.0000008595.14393.77.

COSTA, I.A.S., CUNHA, S.R.S., PANOSSO, R., ARAÚJO, M.F.F., MELO, J.L.S. and ESKINAZISANT'ANNA, E.M. Dinâmica de cianobactérias em reservatórios eutróficos do semi-árido do Rio Grande do Norte. Oecologia Brasiliensis, 2009, 13(2), 382-401.

COSTA, M.R.A., ATTAYDE, J.L. and BECKER, V. Effects of water level reduction on the dynamics of phytoplankton functional groups in tropical semiarid shallow lakes. Hydrobiologia, 2016, 778(1), 75 89. http://dx.doi.org/10.1007/s10750-015-2593-6.

COSTA, M.R.A., MENEZES, R.F., SARMENTO, H., ATTAYDE, J.L., STERNBERG, L.S.L. and BECKER, V. Extreme drought favors potential mixotrophic organisms in tropical semi-arid reservoir. Hydrobiologia, 2019, 831(1), 43-54. http://dx.doi. org/10.1007/s10750-018-3583-2.

DIETER, D., HERZOG, C. and HUPFER, M. Effects of drying on phosphorus uptake in re-flooded lake sediments. Environmental Science and Pollution Research International, 2015, 22(21), 17065-17081. http://dx.doi.org/10.1007/s11356-015-4904-x. PMid:26122575.

FIGUEIREDO, A.L. and BECKER, V. Influence of extreme hydrological events in the quality of water reservoirs in the semi-arid tropical region. Brazilian Journal of Water Resources, 2018, 23, e53.

INTERGOVERNMENTAL PANEL ON CLIMATE CHANGE - IPCC. Climate Change 2014: synthesis report. Geneva: IPCC, 2014.

JEPPESEN, E., BRUCET, S., NASELLI-FLORES, L., PAPASTERGIADOU, E., STEFANIDIS, K., NÓGES, T., NÓGES, P., ATTAYDE, J.L., ZOHARY, T., COPPENS, J., BUCAK, T., MENEZES, R.F., FREITAS, F.R.S., KERNAN, M., SØNDERGAARD, M. and BEKLIOĞLU, M. Ecological impacts of global warming and water abstraction on lakes and reservoirs due to changes in water level and related changes in salinity. Hydrobiologia, 2015, 750(1), 201-227. http://dx.doi. org/10.1007/s10750-014-2169-x.

JEPPESEN, E., KRONVANG, B., MEERHOFF, M., SØNDERGAARD, M., HANSEN, K.M., ANDERSEN, H.E., LAURIDSEN, T.L., LIBORIUSSEN, L., BEKLIOGLU, M., OZEN, A. and OLESEN, J.E. Climate change effects on runoff, catchment phosphorus loading and lake ecological state, and potential adaptations. Journal of Environmental Quality, 2009, 38(5), 19301941. http://dx.doi.org/10.2134/jeq2008.0113. PMid:19704137.

JESPERSEN, A.M. and CHRISTOFFERSEN, K. Measurements of chlorophyll-a from phytoplankton using ethanol as extraction solvent. Hydrobiologia, 1987, 109, 445-454.

MARENGO, J.A. and VALVERDE, M.C. Caracterização do clima no Século XX e Cenário de Mudanças de clima para o Brasil no Século XXI usando os modelos do IPCC-AR4. Revista Multiciência, 2007, 8, 5-28.

MCCUNE, B. and MEFFORD, M.J. PC-ORD: multivariate analysis of ecological data. Version 6. Gleneden Beach: MjM Software Design, 2011.

MEDEIROS, L.C., MATTOS, A., LÜRLING, M. and BECKER, $V$. Is the future blue-green or brown? The effects of extreme events on phytoplankton dynamics in a semi-arid man-made lake. Aquatic Ecology, 2015, 49(3), 293-307. http://dx.doi.org/10.1007/s10452015-9524-5.

MOSS, B., KOSTEN, S., MEERHOF, M., BATTARBEE, R., JEPPESEN, E., MAZZEO, N. and PAERL, H. Allied attack: climate change and eutrophication. Inland Waters, 2011, 1(2), 101-105. http://dx.doi.org/10.5268/IW-1.2.359.

MOURA, A.N., ARAGÃO-TAVARES, N.K.C. and AMORIM, C. Cyanobacterial blooms in freshwater bodies from a semiarid region, Northeast Brazil: A review. Journal of Limnology, 2018, 77(2), 179-188. 
MURPHY, J. and RILEY, J.P. A modified single solution method for the determination of phosphate in natural waters. Analytica Chimica Acta, 1962, 27, 31-36. http://dx.doi.org/10.1016/S0003-2670(00)88444-5.

ÖZEN, A., KARAPINAR, B., KUCUK, İ., JEPPESEN, E. and BEKLIOGLU, M. Drought-induced changes in nutrient concentrations and retention in two shallow Mediterranean lakes subjected to different degrees of management. Hydrobiologia, 2010, 646(1), 61-72. http://dx.doi.org/10.1007/s10750010-0179-x.

PANOSSO, R., COSTA, I.A.S., SOUZA, N.R., ATTAYDE, J.L., CUNHA, S.R.S. and GOMES, F.C.F. Cianobactérias e cianotoxinas em reservatórios do Estado do Rio Grande do Norte e o potencial controle das floraçóes pela Tilápia do Nilo (Oreochromis niloticus). Oecologia Brasiliensis, 2007, 11(3), 433-449. http://dx.doi.org/10.4257/ oeco.2007.1103.12.

PROPHET, C. W. Limnological features of Lyon County Lake after drainage and reflooding. The Southwestern Naturalist, 1970, 14(3), 317-325. http://dx.doi. org/10.2307/3668959.

REBOUÇAS, A.C. Água na região Nordeste: desperdício e escassez. Instituto de Estudos Avançados da Universidade de São Paulo, 1997, 11(29), 127-154. http://dx.doi. org/10.1590/S0103-40141997000100007.

ROLAND, F., HUSZAR, V.L.M., FARJALLA, V.F., ENRICH-PRAST, A., AMADO, A.M. and OMETTO, J.P.H.B. Climate change in Brazil: perspective on the biogeochemistry of inland waters. Brazilian Journal of Biology $=$ Revista Brasileira de Biologia, 2012, 72(3), 709-722, Supplement. http:// dx.doi.org/10.1590/S1519-69842012000400009. PMid:23011300.

SCHOLZ, O., GAWNE, B., EBNER, B., ELLIS, I., BETTS, F. and MEREDITH, S. The impact of drying on the ecology of the menindee lakes. technical report. Australia: Cooperative Research Centre for Freshwater Ecology, 1999.

SCHOLZ, O., GAWNE, B.E.N., EBNER, B. and ELLIS, I. The effects of drying and re-flooding on nutrient availability in ephemeral deflation basin lakes in western New South Wales, Australia. River Research and Applications, 2002, 18(2), 185-196. http://dx.doi.org/10.1002/rra.665.

SECRETARIA DE ESTADO DO MEIO AMBIENTE E DOS RECURSOS HÍDRICOS DO RIO GRANDE DO NORTE - SEMARH. [online]. Natal: SEMARH, 2001. [viewed 1 April 2017]. Available from: http://www.semarh.rn.gov.br/

STRAŠKRABA, M., and TUNDISI, J.G. Reservoir ecosystem functioning: theory and application. In: J.G. TUNDISI and M. STRASKRABA. Theoretical Reservoir Ecology and its Applications. São Carlos: Brazilian Academy of Sciences International Institut of Ecology and Backhuuis Publishers, 1999, pp. 565-597.

TEFERI, M., DECLERCK, S.A., DE BIE, T., LEMMENS, P., GEBREKIDAN, A., ASMELASH, T. and SNOEKS, J. Strong effects of occasional drying on subsequent water clarity and cyanobacterial blooms in cool tropical reservoirs. Freshwater Biology, 2014, 59(4), 870-884. http://dx.doi.org/10.1111/ fwb. 12312 .

THORNTON, J.A. and RAST, W. A test of hypothesis relating to the comparative limnology and assessment of eutrophication in semi-arid manmade lakes. In: M. Straskraba, J.G. Tundisi and A. Duncan, eds. Comparative reservoir limnology and water quality management. Dordrecht: Kluwer Academic Publishers, 1993, pp. 1-24. http://dx.doi. org/10.1007/978-94-017-1096-1_1.

VALDERRAMA, J.C. The simultaneous analysis of total nitrogen and total phosphorus in natural waters. Marine Chemistry, 1981, 10(2), 109-122. http:// dx.doi.org/10.1016/0304-4203(81)90027-X

VAN GEEST, G.J., COOPS, H., ROIJACKERS, R.M.M., BUIJSE, A.D. and SCHEFFER, M. Succession of aquatic vegetation driven by reduced water-level fluctuations in floodplain lakes. Journal of Applied Ecology, 2005, 42(2), 251-260. http://dx.doi. org/10.1111/j.1365-2664.2005.00995.x.

Received: 28 September 2018 Accepted: 13 March 2019 